\title{
Germination and Seedling Growth Response of Sprouts and Leafy Vegetables after Applying Oxygen Nanobubble Water
}

\author{
Seo Youn Lee ${ }^{1^{\dagger}}$, Seo Hee Jung ${ }^{\dagger}$, Ah Ram Cho ${ }^{2}$, Myung Syun Shim ${ }^{3}$, You Kyung Chung ${ }^{4}$, and Yoon Jin Kim ${ }^{5^{*}}$ \\ 1 Undergraduate student, Department of Horticulture, Biotechnology and Landscape Architecture, Seoul Women's University, Seoul \\ 01797, Republic of Korea \\ ${ }^{2}$ Postdoctoral researcher, Department of Horticulture, Biotechnology and Landscape Architecture, Seoul Women's University, Seoul \\ 01797, Republic of Korea \\ ${ }^{3}$ Cooperation researcher, Department of Horticulture, Biotechnology and Landscape Architecture, Seoul Women's University, Seoul \\ 01797, Republic of Korea \\ ${ }^{4}$ Doctoral student, Department of Horticulture, Biotechnology and Landscape Architecture, Seoul Women's University, Seoul 01797, \\ Republic of Korea \\ ${ }^{5}$ Professor, Department of Horticulture, Biotechnology and Landscape Architecture, Seoul Women's University, Seoul 01797, Republic of Korea
}

\section{ABSTRACT}

Background and objective: The nanobubbles remain stable in water, and it increased dissolved oxygen (DO) in the water that promotes the seed germination and the plant growth. We evaluated the seed germination and growth of sprouts (radish, wheat, and barley) and leafy vegetables (red mustard and pak choi) when irrigated with various DO of nanobubble water (NB). Methods: The oxygen NB was generated by surface friction and treated in 4 levels: NB 0\% (control, DO $9.21 \mathrm{mg} \cdot \mathrm{L}^{-1}$ ), $\mathrm{NB}$ 20\% (DO $15.40 \mathrm{mg} \cdot \mathrm{L}^{-1}$ ), NB 33\% (DO $20.93 \mathrm{mg} \cdot \mathrm{L}^{-1}$ ), and NB 100\% (DO $39.29 \mathrm{mg} \cdot \mathrm{L}^{-1}$ ).

Results: The root length of radish and wheat increased more in NB 33\% than the control plot. The fresh weight increased in NB 33\% compared to the control plot in radish and wheat, and both fresh and dry weight increased more in NB 20\%, NB $33 \%$, and NB 100\% than the control plot of barley. The leaf length and width of red mustard decreased more in NB 33\% and NB 100\% than the control plot and NB 20\%, which indicated the leaf compactness. The fresh and dry weight of shoot and root increased more in NB 100\% than the control plot in red mustard. In pak choi, the shoot fresh weight increased more in NB 100\% than the control plot. In leafy vegetables, the germination rate of red mustard in NB 100\% was higher than the control plot, however, it was not significantly different between oxygen NB plots in sprout vegetables.

Conclusion: The results showed that the root growth and biomass increased after applying NB 33\% in sprout vegetables. The leaf growth properties as the number of leaves and leaf size were not significantly different or decreased in NB treatments compared to control plots, but NB 100\% (DO $39.29 \mathrm{mg} \cdot \mathrm{L}^{-1}$ ) effectively increased the root growth and plant biomass in leafy vegetables.

Keywords: biomass, dissolved oxygen, plant growth, sustainable agricultural watering, vegetable cultivation

\section{Introduction}

Nanobubbles are microbubbles smaller than $0.2 \mu \mathrm{m}$
(Jung et al., 2016) and are applied to various fields such as surface washing, water purification, growth promotion, and fluid friction reduction with their unique physical prop-

\footnotetext{
${ }^{\dagger}$ Seo Youn Lee and Seo Hee Jung are contributed equally to this paper

This study is supported by the National Research Foundation of Korea Mid-career Research Grant (NRF-2018R1A2B6007834), Ministry of Science \& ICT and Institute for Information \& Communications Technology Promotion SW University Grant (2016-0-00022), and Seoul Women's University research fund (2021-0106). We would like to express our gratitude to Seoul Women's University professor emeritus Jong-Suk Lee and Fawoo Nanotech CEO Young-Ho Yoo for their support.

Received: September 23, 2021, Revised: October 12, 2021, Accepted: October 25, 2021

First author: Seo Youn Lee, sn879042@swu.ac.kr, (10) https://orcid.org/000-0001-8048-7610

*Corresponding author: Yoon Jin Kim, yj1082@swu.ac.kr, (D) https://orcid.org/0000-0003-2260-1563
} 
erties (Liu et al., 2013; Song et al., 2013). Nanobubbles are affected by less buoyancy than macrobubbles $(\geq 50$ $\mu \mathrm{m})$ or microbubbles $(10-50 \mu \mathrm{m})$ due to nanosized bubble diameter and rise very slowly, which is why they remain in liquid for a long time (Jeong et al., 2017). Shock waves generated as nanobubbles break apart in nanobubble water promote formation of highly reactive hydroxyl radical $(-\mathrm{OH})$ and effectively decompose organic matter, thereby enabling water purification (Ahmed et al., 2018).

In general, the amount of dissolved oxygen (DO) contained in water is 1-3 ppm for groundwater and 3-4 ppm for tap water or purified water. Compared to groundwater, tap water, and purified water, nanobubble water includes 45-60 times more DO (Song et al., 2013). Lower oxygen content of soil inhibits root respiration and growth (Greenway et al., 2006). Supplying sufficient oxygen to the root zone of plants promotes absorption of soil moisture and nutrients, thereby increasing crop yield (Du et al., 2018; Sang et al., 2018; Zhou et al., 2019). The germination rate of barley was $58 \%$ in 17 hours of the experiment after applying oxygen nanobubble water that has $15-25 \%$ higher DO than distilled water, thereby showing a $28 \%$ increase compared to applying distilled water (Liu et al., 2016). Increasing DO is effective in plant cultivation, but the extent varies depending on the crop. When micro-nanobubble is applied with DO $15 \mathrm{mg} \cdot \mathrm{L}^{-1}$ to tomatoes and cucumbers, soil enzyme content and the amount of beneficial soil microbes increased in root zone soil (Zhou et al., 2019). Moreover, leaf length, leaf width, number of leaves, and leaf area of lettuce increased in the plant applying DO 8.6 $\mathrm{mg} \cdot \mathrm{L}^{-1}$ using microbubbles compared to the control plot (DO $6.15 \mathrm{mg} \cdot \mathrm{L}^{-1}$ ) (Abu-Shahba et al., 2021). Vitamin C and water-soluble sugar content were highest in the 15 $\mathrm{mg} \cdot \mathrm{L}^{-1}$ treatment plot (Zhou et al., 2019). It is necessary to explore the most suitable oxygen nanobubble water concentration for germination and growth of each crop.

The propensity to consume fresh foods is constantly growing in terms of choosing and consuming plants based on increased living standard and income (Jun et al., 2012). Due to the change in dietary culture, vegetable sprouts and leafy vegetables for wraps are receiving attention. Sprouts refer to edible fresh shoots from seeds at an early stage of growth, and they are harvested quickly with the growth duration of 3-7 days (Lee et al., 2011). The market size for sprouts accounts for about $3 \%$ of the whole market, and starting with radish sprouts in the 1980s, various sprouts are being cultivated in the 2000s such as Leguminosae, Gramineae, and Cruciferae (Seo, 2013). Leafy vegetables have lower calories than other foods and include many important nutrients necessary for maintaining health, and thus the consumption propensity is increasing along with the change in food consumption patterns (Jun et al., 2012; Lee et al., 2016; Lee, 2017). Among leafy vegetables, cruciferous vegetables reduce the risk of diseases such as cancer and diabetes, have a powerful antioxidant effect, and are beneficial for health (Lee, 2017). Red mustard among cruciferous vegetables is a popular and typical red vegetable (Rural Development Administration [RDA], 2018), and pak choi is well received by consumers for its high content of antioxidant glucosinolates (Podsędek et al., 2007).

This experiment was conducted to investigate the effect on seed germination and seedling growth when applying oxygen nanobubble water in various DO concentrations in substrate cultivation of 3 types of sprouts and 2 types of leafy vegetables commonly consumed in Korea and determine an effective DO concentration.

\section{Research Methods}

\section{Materials and growth environment}

There are 3 types of materials for the experiment of sprouts: seeds of radish sprouts (Raphanus sativus L.) and wheat sprouts (Triticum aestivum) cultivated in Namyangju-si, Gyeonggi-do, and barley sprouts (Hordeum vulgare var. hexastichon) cultivated in Gwangju-si, Gyeonggi-do. There are 2 types of materials for the experiment of leafy vegetables: seeds of red mustard (Brassica juncea L.) and pak choi (Brassica campestris L. ssp. chinensis Jusl.) cultivated in Cheoin-gu, Yongin-si, Gyeonggi-do. The seeds of sprouts and leafy vegetables were arranged in horticultural substrate (FarmHannong, Korea) with a three-stage repeated batch in a 50 -cell tray (width $5 \mathrm{~cm}$, length $5 \mathrm{~cm}$, height $5.5 \mathrm{~cm}$, volume $73 \mathrm{~mL}$ ) immediately after purchase. 
Table 1. Average concentrations of dissolved oxygen (DO), water temperature, $\mathrm{EC}$, and $\mathrm{pH}$ of the volume ratio of the nanobubble water (NB) : tap water of 0:1 (NB 0\%), 1:4 (NB 20\%), 1:2 (NB 33\%), and 1:0 (NB 100\%) treated solution after sowing

\begin{tabular}{ccccc}
\hline Treatment & DO $\left(\mathrm{mg} \cdot \mathrm{L}^{-1}\right)$ & Water temperature $\left({ }^{\circ} \mathrm{C}\right)$ & $\mathrm{EC}\left(\mathrm{dS} \cdot \mathrm{m}^{-1}\right)$ & $\mathrm{pH}$ \\
\hline NB $0 \%$ & 9.21 & 19.5 & 0.16 & 6.5 \\
NB $20 \%$ & 15.40 & 19.8 & 0.16 & 6.5 \\
NB 33\% & 20.93 & 19.4 & 0.14 & 6.4 \\
NB $100 \%$ & 39.29 & 19.2 & 0.14 & 6.4 \\
\hline
\end{tabular}

The seeds of leafy vegetables were planted after filling up the plastic pot No. 11 (external diameter $110 \mathrm{~mm}$, height $100 \mathrm{~mm}$, volume $580 \mathrm{~mL}) 3$ weeks after sowing by randomly selecting 11 stocks for each treatment plot. The experiments of sprouts and leafy vegetables were conducted in the glass greenhouse of Seoul Women's University. The experiment of sprouts was conducted for 7 days after sowing from March 4 to 11 in lab settings with average daytime temperature of $17.5^{\circ} \mathrm{C}$, average nighttime temperature of $10.0^{\circ} \mathrm{C}$, average humidity of $66 \%$, and average daytime luminous intensity of $294 \mu \mathrm{mol} \cdot \mathrm{m}^{-2} \cdot \mathrm{s}^{-1}$. The experiment of leafy vegetables was conducted for 45 days from May 13 to June 26, 2021 in lab settings retained at $25 \pm 2 / 20 \pm$ $2^{\circ} \mathrm{C}$, average humidity of $73 \%$, and average daytime luminous intensity of $161 \mu \mathrm{mol} \cdot \mathrm{m}^{-2} \cdot \mathrm{s}^{-1}$.

\section{Application of oxygen nanobubble water}

Irrigation water used in the experiment was prepared by mixing tap water and oxygen nanobubble water (NB) created in surface friction from the oxygen concentrator (CR-P3W, Fawoo Nanotech Co. Ltd., Korea) and nanobubble generator (SNT-03, Fawoo Nanotech Co. Ltd., Korea) in a fixed ratio. It was applied in 4 different types of oxygen NB volume: tap water volume $=0: 1$ (control plot, NB 0\%), 1:4 (NB 20\%), 1:2 (NB 33\%), 1:0 (NB $100 \%$ ) depending on the ratio of NB and tap water. Both sprouts and leafy vegetables were watered $500 \mathrm{~mL}$ per tray 3 times a week in seed germination stage. Leafy vegetables were watered $200 \mathrm{~mL}$ per pot 2 times a week considering the substrate capacity that increased after transplantation. We examined DO, water temperature, electrical conductivity (EC), and $\mathrm{pH}$ of all treatment plots according to the ratio of NB and tap water in watering (Table 1). DO and water temperature were measured using a DO measuring instrument (HI5421 research grade DO bench meter, HANNA Instruments, USA). DO was $9.21 \mathrm{mg} \cdot \mathrm{L}^{-1}$ in NB $0 \%$ treatment plot, $15.40 \mathrm{mg} \cdot \mathrm{L}^{-1}$ in NB $20 \%$ treatment plot, $20.93 \mathrm{mg} \cdot \mathrm{L}^{-1}$ in NB $33 \%$ treatment plot, and $39.29 \mathrm{mg} \cdot \mathrm{L}^{-1}$ in NB $100 \%$ treatment plot. Water temperature ranged from 19.0 to $20.0^{\circ} \mathrm{C}$. EC and $\mathrm{pH}$ were measured using a mobile $\mathrm{pH} / \mathrm{EC} / \mathrm{TDS} /$ temperature measuring instrument (HI 9811-5, HANNA Instruments, USA). To obtain only the effect of oxygen NB, we cultivated sprouts and leafy vegetables without using a nutrient solution. The average EC of irrigation water was adjusted to the range of $0.14-0.16 \mathrm{dS} \cdot \mathrm{m}^{-1}$, and $\mathrm{pH}$ to $6.4-6.5$, which is the adequate range for growth of leafy vegetables.

\section{Measurement items}

Germination rate of sprouts was investigated for 7 days after sowing, and that of leafy vegetables for 5 days after sowing. Germination rate of the last day of investigation was calculated using Equation 1. Mean germination time was calculated using Equation 2.

Germination rate $=($ Number of seeds germinated $/$ total number of seeds) $\times 100 \% \quad$---- (Equation 1)

Mean germination time $=\Sigma$ (days after sowing $\times$ number of germinations on the day of the investigation) / total number of germinations ---- (Equation 2)

Seedling growth of sprouts was investigated by measuring plant length, root length, fresh weight, and dry weight on 7 days after sowing. Plant length of sprouts was obtained by measuring the full length of the shoot, and root length by measuring the longest root. For leafy vegetables, leaf length, leaf width, number of leaves, leaf area, plant length, and root length were measured with 11 stocks plant- 
Table 2. The seed germination rate and mean germination time of sprouts and leafy vegetables irrigated with the volume ratio of the oxygen nanobubble water (NB) : tap water of 0:1 (NB 0\%), 1:4 (NB 20\%), 1:2 (NB 33\%), and 1:0 (NB 100\%)

\begin{tabular}{|c|c|c|c|c|}
\hline Vegetables type & Crop species & Treatment & Germination rate $(\%)^{\mathrm{z}}$ & Mean germination time (days) \\
\hline \multirow{12}{*}{ Sprouts } & \multirow{4}{*}{ Radish } & NB $0 \%$ & $70.7 \pm 2.9 \mathrm{a}^{\mathrm{y}}$ & $5.23 \pm 0.11 \mathrm{a}$ \\
\hline & & NB $20 \%$ & $61.3 \pm 0.7 \mathrm{a}$ & $5.55 \pm 0.12 \mathrm{a}$ \\
\hline & & NB 33\% & $70.0 \pm 4.2 \mathrm{a}$ & $5.39 \pm 0.22 \mathrm{a}$ \\
\hline & & NB $100 \%$ & $68.7 \pm 2.4 \mathrm{a}$ & $5.42 \pm 0.30 \mathrm{a}$ \\
\hline & \multirow{4}{*}{ Wheat } & NB $0 \%$ & $83.3 \pm 5.2 \mathrm{a}$ & $6.43 \pm 0.19 \mathrm{a}$ \\
\hline & & NB $20 \%$ & $77.3 \pm 0.7 \mathrm{a}$ & $6.35 \pm 0.36 \mathrm{a}$ \\
\hline & & NB 33\% & $74.7 \pm 2.4 \mathrm{a}$ & $6.52 \pm 0.31 \mathrm{a}$ \\
\hline & & NB $100 \%$ & $76.7 \pm 0.7 \mathrm{a}$ & $6.70 \pm 0.34 \mathrm{a}$ \\
\hline & \multirow{4}{*}{ Barley } & NB $0 \%$ & $92.0 \pm 1.2 \mathrm{a}$ & $5.81 \pm 0.17 \mathrm{a}$ \\
\hline & & NB $20 \%$ & $83.3 \pm 1.3 \mathrm{a}$ & $5.66 \pm 0.21 \mathrm{a}$ \\
\hline & & NB 33\% & $90.0 \pm 1.5 \mathrm{a}$ & $5.78 \pm 0.21 \mathrm{a}$ \\
\hline & & NB $100 \%$ & $92.0 \pm 0.0 \mathrm{a}$ & $5.92 \pm 0.27 \mathrm{a}$ \\
\hline \multirow{8}{*}{ Leafy } & \multirow{4}{*}{ Red mustard } & NB $0 \%$ & $93.3 \pm 0.7 \mathrm{bc}$ & $2.50 \pm 0.03 \mathrm{a}$ \\
\hline & & NB $20 \%$ & $95.3 \pm 1.3 \mathrm{ab}$ & $2.43 \pm 0.11 \mathrm{a}$ \\
\hline & & NB 33\% & $91.3 \pm 0.7 \mathrm{c}$ & $2.59 \pm 0.02 \mathrm{a}$ \\
\hline & & NB $100 \%$ & $96.7 \pm 0.7 \mathrm{a}$ & $2.38 \pm 0.06 \mathrm{a}$ \\
\hline & \multirow{4}{*}{ Pak choi } & NB $0 \%$ & $91.3 \pm 2.9 \mathrm{a}$ & $2.57 \pm 0.13 \mathrm{a}$ \\
\hline & & NB $20 \%$ & $92.0 \pm 2.0 \mathrm{a}$ & $2.42 \pm 0.02 \mathrm{a}$ \\
\hline & & NB 33\% & $91.3 \pm 0.7 \mathrm{a}$ & $2.68 \pm 0.06 \mathrm{a}$ \\
\hline & & NB $100 \%$ & $92.7 \pm 1.3 \mathrm{a}$ & $2.49 \pm 0.10 \mathrm{a}$ \\
\hline
\end{tabular}

${ }^{\mathrm{z}}$ The germination rate was measured at 7 days and 5 days after sowing in sprouts and leafy vegetables, respectively.

${ }^{\mathrm{y}} \mathrm{Mean} \pm$ S.E. separation by Duncan's multiple range test, $p \leq .05(\mathrm{n}=3)$.

ed in each treatment plant every 5 days after sowing. Considering that red mustard is harvested when there are 8 foliage leaves (RDA, 2018), and pak choi when the average plant length is $14 \mathrm{~cm}$ or longer (RDA, 2013), we measured leaf growth items of leafy vegetables until 45 days after sowing when both leafy vegetables reach the harvesting standard. Leaf length was obtained by measuring the longest part including leaf stalk, and leaf width by measuring the widest part in terms of leaf width. The number of leaves was obtained by measuring all leaves that are $1 \mathrm{~cm}$ or more, and leaf area by measuring the area of all leaves including leaf stalk by applying the leaf length measurement standard, using ImageJ software (v1.8.0_112, NIH, USA). Plant length was obtained by measuring up to the highest part of the plant body vertically from the ground when planted. Fresh weight of the shoot and root show the results of 30 days after sowing considering the general seedling culture period (approximately 30 days) of leafy vegetables. Dry weight of plants measured by drying the plants for 5 days at $60^{\circ} \mathrm{C}$ dry oven.

\section{Statistical processing}

The seedling trays and planting pots for sowing were in completely randomized design. The results were statistically processed using $\mathrm{R}$, and the statistical significance of each process was determined by Duncan's multiple range test $(p \leq .05)$. The graphs were drawn using SigmaPlot (v10.0, Systat Software Inc., USA).

\section{Results and Discussion}

Germination rates in all sprouts did not show a difference between the control plot and NB treatment plots in 7 days after sowing (Table 2), but in leafy vegetables, germination rates of red mustard were $93.3 \%, 95.3 \%, 91.3 \%$, and $96.7 \%$ in NB $0 \%$, NB $20 \%$, NB $33 \%$, and NB $100 \%$ 
treatment plots in 5 days after sowing and the rate was high in NB $100 \%$ treatment plot compared to the control plot (NB $0 \%$ ) (Table 1). As a result of increasing the DO to $8 \mathrm{mg} \cdot \mathrm{L}^{-1}$ using microbubbles on barley seeds, the germination rate increased significantly compared to the control plot (distilled water), showing the highest significance ( $p$ $\leq .001)$ especially around 18 hours of treatment during the experiment. Thus, NB showed a close correlation at the initial stage of germination of barley seeds (Hwang et al., 2016). When applying two types of oxygen NB (DO $8,40 \mathrm{mg} \cdot \mathrm{L}^{-1}$ ) to spinach and carrot seeds, the germination rate increased by at least $9 \%$ when DO increased (Liu et al., 2016). It was predicted that the germination rate will increase along with DO; but comparing the germination rate of red mustard in treatment plots, it was found that the rate of NB 33\% treatment plot decreased compared to $\mathrm{NB} 20 \%$ treatment plot, and the rate was highest in NB $100 \%$ treatment plot (Table 1). Excessively high DO concentration may destroy the cells or cause diseases in the body (Bailly et al., 2008). In canola, osmotic pressure and physical stress occurred with hydroxyl radical generated from microbubbles when DO concentration was supersaturated (9-11 $\mathrm{mg} \cdot \mathrm{L}^{-1}$ ) (Ikeura et al., 2017). In NB 20\% treatment plot of this study, the germination rate increased with DO concentration of approximately $15 \mathrm{mg} \cdot \mathrm{L}^{-1}$, but the germination rate may have decreased in NB 33\% treatment plot with DO concentration of approximately 21 $\mathrm{mg} \cdot \mathrm{L}^{-1}$ due to supersaturation of DO concentration that inhibited growth. Hwang et al. (2016) and Liu et al. (2016) applied NB by immersing the seeds in oxygen sponges and beakers. However, this study conducted the experiment by sowing the seeds in horticultural substrates and watering them with oxygen NB considering the actual cultivating conditions. Thus, there may be an effect of organic matter in horticultural substrates that may have increased the germination rate of red mustard significantly in NB 100\% treatment plot. Accordingly, the adequate DO is presumed to be NB $20 \%$ to increase the germination rate of red mustard. For other leafy vegetables except red mustard and sprouts, there was no difference between the control plot and treatment plots in germination rates and mean germination time of all materials, indicating that oxygen NB did not have much effect on germination. However, consider-



Fig. 1. The leaf length and leaf width, the number of leaves, and the total leaf area of red mustard (A, B, E, F) and pak choi (C, D, G, H) irrigated the volume ratio of the oxygen nanobubble: tap water of 0:1 (NB 0\%), 1:4 (NB 20\%), 1:2 (NB 33\%), and 1:0 (NB 100\%). Error bars represent means \pm S.E. $[n=11(A, B, C, D)$ and $n=3(E$, $F, G, H)]$ and values followed by different letters are significantly different according to Duncan's multiple range test at $p \leq .05$.

ing the germination rate, red mustard is expected to see a stable increase in the germination rate within the DO concentration range of $15.40 \mathrm{mg} \cdot \mathrm{L}^{-1}$ (NB 20\%).

For leafy vegetables, leaf length and leaf width of red mustard were higher in NB 33\% treatment in 5 days after sowing of the experiment than the control plot, but tended to decrease from 35 to 45 days after sowing in NB 33\% and NB $100 \%$ treatment plots compared to the control plot and NB 20\% treatment plot (Figs. 1A-1D). Number of leaves and leaf area of leafy vegetables did not show a difference in NB treatment plots regardless of plant type (Figs. 1E-1H). Number of leaves and leaf length of cruciferous Brassica campestris increased in the treatment plot where oxygen nanobubbles concentration was increased to $31.7 \mathrm{mg} \cdot \mathrm{L}^{-1}$ compared to the control plot with $7.7 \mathrm{mg} \cdot \mathrm{L}^{-1}$ 
Table 3. The seedling height, root length, fresh weight, and dry weight of sprout vegetables irrigated with the volume ratio of the oxygen nanobubble water (NB) : tap water of 0:1 (NB 0\%), 1:4 (NB 20\%), 1:2 (NB 33\%), and 1:0 (NB 100\%) at 7 days after sowing

\begin{tabular}{|c|c|c|c|c|c|}
\hline \multirow{2}{*}{ Crop species } & \multirow{2}{*}{ Treatment } & \multirow{2}{*}{ Seedling height $(\mathrm{cm})$} & \multirow{2}{*}{ Root length (cm) } & \multicolumn{2}{|c|}{ Weight (g) } \\
\hline & & & & Fresh & Dry \\
\hline \multirow[t]{4}{*}{ Radish } & NB $0 \%$ & $3.71 \pm 0.10 \mathrm{a}^{\mathrm{z}}$ & $2.44 \pm 0.14 b$ & $0.103 \pm 0.005 b$ & $0.0049 \pm 0.0006 \mathrm{a}$ \\
\hline & NB $20 \%$ & $3.65 \pm 0.19 \mathrm{a}$ & $2.19 \pm 0.17 \mathrm{~b}$ & $0.121 \pm 0.007 \mathrm{ab}$ & $0.0095 \pm 0.0004 \mathrm{a}$ \\
\hline & NB 33\% & $3.84 \pm 0.13 \mathrm{a}$ & $4.50 \pm 0.42 \mathrm{a}$ & $0.127 \pm 0.007 \mathrm{a}$ & $0.0125 \pm 0.0062 \mathrm{a}$ \\
\hline & NB $100 \%$ & $3.39 \pm 0.17 \mathrm{a}$ & $2.69 \pm 0.26 b$ & $0.101 \pm 0.008 \mathrm{~b}$ & $0.0052 \pm 0.0008 \mathrm{a}$ \\
\hline \multirow[t]{4}{*}{ Wheat } & NB $0 \%$ & $5.02 \pm 0.22 \mathrm{ab}$ & $4.64 \pm 0.65 b$ & $0.119 \pm 0.004 \mathrm{~b}$ & $0.0361 \pm 0.0018 \mathrm{a}$ \\
\hline & NB $20 \%$ & $4.67 \pm 0.15 b$ & $5.94 \pm 0.43 \mathrm{ab}$ & $0.114 \pm 0.005 b$ & $0.0323 \pm 0.0019 \mathrm{a}$ \\
\hline & NB 33\% & $4.83 \pm 0.19 \mathrm{ab}$ & $6.51 \pm 0.37 \mathrm{a}$ & $0.143 \pm 0.009 \mathrm{a}$ & $0.0374 \pm 0.0020 \mathrm{a}$ \\
\hline & NB $100 \%$ & $5.32 \pm 0.10 \mathrm{a}$ & $5.75 \pm 0.53 \mathrm{ab}$ & $0.127 \pm 0.005 \mathrm{ab}$ & $0.0356 \pm 0.0023 \mathrm{a}$ \\
\hline \multirow[t]{4}{*}{ Barley } & NB $0 \%$ & $6.09 \pm 0.24 \mathrm{a}$ & $8.36 \pm 0.60 \mathrm{a}$ & $0.153 \pm 0.009 \mathrm{~b}$ & $0.0095 \pm 0.0010 \mathrm{~b}$ \\
\hline & NB $20 \%$ & $6.67 \pm 0.29 \mathrm{a}$ & $8.80 \pm 0.38 \mathrm{a}$ & $0.199 \pm 0.012 \mathrm{a}$ & $0.0217 \pm 0.0012 \mathrm{a}$ \\
\hline & NB 33\% & $6.56 \pm 0.19 a$ & $9.29 \pm 0.32 \mathrm{a}$ & $0.196 \pm 0.009 \mathrm{a}$ & $0.0254 \pm 0.0009 \mathrm{a}$ \\
\hline & NB $100 \%$ & $6.73 \pm 0.20 \mathrm{a}$ & $9.27 \pm 0.31 \mathrm{a}$ & $0.206 \pm 0.009 \mathrm{a}$ & $0.0228 \pm 0.0012 \mathrm{a}$ \\
\hline
\end{tabular}

${ }^{\mathrm{z}}$ Mean \pm S.E. separation by Duncan's multiple range test, $p \leq .05(\mathrm{n}=15)$.

(Ebina et al., 2013). Moreover, for lettuce, leaf length, leaf width, number of leaves, and leaf area increased with statistical significance $(p \leq .05)$ when applying microbubble water with $\mathrm{DO}$ concentration of $8.6 \mathrm{mg} \cdot \mathrm{L}^{-1}$ compared to the control plot (DO $6.15 \mathrm{mg} \cdot \mathrm{L}^{-1}$ ) (Abu-Shahba et al., 2021). On the other hand, leaf length and leaf width of watercress did not show a significant difference between the control plot and the treatment plot applying microbubbles (Bok et al., 2019). Ahmed et al. (2018) reported that, after applying oxygen nanobubbles to tomatoes, carrots, and horse beans cultivated in soil, leaf number of tomatoes increased significantly, but there was no effect on carrots and horse beans, and leaf length did not have significance in all plants. Thus, the treatment effect of oxygen nanobubbles varies depending on plant type.

In the sprout experiment of this study, the seedling height did not show a difference between the control plot and NB treatment plots depending on DO (Table 3). The plant height of leafy vegetables was not significantly different between all NB treatment plots compared to the control plot at 15 and 20 days after sowing, but those in NB 20\% increased than the control plot at 45 days after sowing in red mustard (Fig. 2A). In pak choi, the plant height increased constantly in 15,20 , and 35 days after sowing in some concentrations when applying NB (Fig. 2C). It tended to increase in all NB treatment plots compared to the control plot at 40 days after sowing, but there was no difference between treatment plots in 45 days after sowing. This study did not additionally apply nutrient solutions to examine the effect of oxygen NB on germination and growth of fresh foods such as sprouts and leafy vegetables in cultivation; rather, it supplied a low level of EC at $0.14-0.16$ $\mathrm{dS} \cdot \mathrm{m}^{-1}$ to determine only the effect of DO concentration (Table 1). Pak choi is a crop that has a high need for nutrients, and EC 1.8 and $2.4 \mathrm{dS} \cdot \mathrm{m}^{-1}$ are reported as the suitable nutrient concentrations for growth of pak choi. Low EC of $0.0-0.6 \mathrm{dS} \cdot \mathrm{m}^{-1}$ induces nutrient stress, which may inhibit growth and deteriorate the quality of pak choi (Ding et al., 2018). Thus, the low EC of oxygen NB may not show any effect on the height of sprout or leafy vegetables at 45 days after sowing, which is the final point of the experiment.

Generation methods of microbubbles like nanobubbles include pressurized dissolution type, gas circulating type, gas-liquid swirling flow type, etc. (Yoon et al., 2013), and there may be a difference in plant growth depending on the generation method of microbubbles. When applying microbubbles generated by pressurized dissolution type, the iron in the culture medium may be oxidized, possibly inhibiting plant growth such as plant length and dry weight 


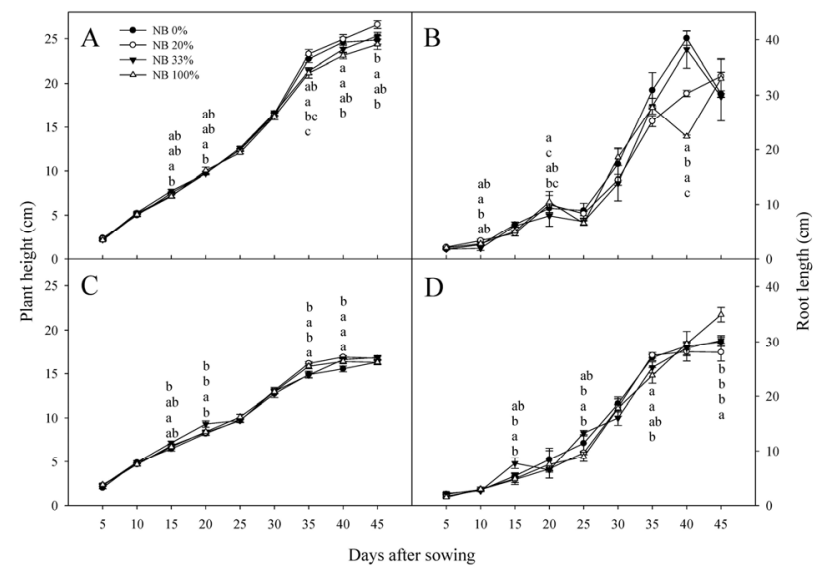

Fig. 2. The plant height and the root length of red mustard (A, B) and those of pak choi (C, D) irrigated the volume ratio of the oxygen nanobubble: tap water of $0: 1$ (NB 0\%), 1:4 (NB 20\%), 1:2 (NB 33\%), and 1:0 (NB $100 \%)$. Error bars represent means \pm S.E. $[n=11(A, C)$ and $n=3(B, D)$ ] and values followed by different letters are significantly different according to Duncan's multiple range test at $p \leq .05$.

(Ikeura et al., 2017). Nanobubbles in this experiment were generated using frictional force. Unlike previous studies, this study cultivated the plants using substrates instead of hydroponics, and thus did not use the hydroponics system or nutrient solutions in the experiment. However, physicochemical characteristics of bubbles vary depending on how microbubbles are generated, and there may be an effect on nutrient and water absorption of roots due to the energy accumulated in the bubbles as well as generated radicals (Bok et al., 2019). The generation method of nanobubbles may also have affected plant growth in this study. Thus, it is necessary to conduct additional research analyzing the physicochemical characteristics of bubbles when applying oxygen nanobubbles using frictional force and the nutrient and water adsorption capacity of roots.

Barley sprouts and red mustard showed an increase in both fresh weight and dry weight of the shoot and root in all treatment plots and NB 100\% treatment plot, respectively, compared to the control plot. In particular, fresh weight and dry weight of the root of red mustard increased by $55 \%$ and $47 \%$, respectively, in NB $100 \%$ treatment plot compared to the control plot (Fig. 3). Weight is an important indicator that determines the growth condition or relative growth rate of crops (Kim et al., 2016). Moreover,

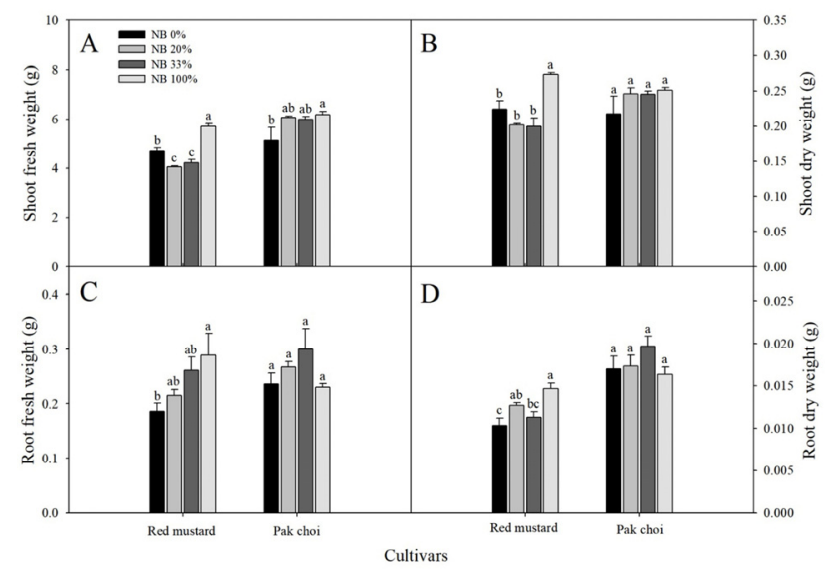

Fig. 3. The shoot fresh weight (A), the shoot dry weight (B), the root fresh weight (C), the root dry weight (D) of red mustard and those of pak choi irrigated the volume ratio of the oxygen nanobubble: tap water of 0:1 (NB 0\%), $1: 4$ (NB 20\%), 1:2 (NB 33\%), and 1:0 (NB 100\%) at 30 days after sowing. Error bars represent means \pm S.E. $(n=3)$ and values followed by different letters are significantly different according to Duncan's multiple range test at $p \leq .05$.

dry weight is one of the key factors in expressing the relationship between crop growth and the environment and determining the biomass of crop harvest season (Both et al., 1994). Root length of radish sprouts and wheat sprouts increased in NB 33\% treatment plot compared to the control plot (Table 3). The root length of red mustard did not show any difference between the control plot and NB treatment plots in 45 days after sowing, but it increased more in NB $100 \%$ treatment plots than the control plot in pak choi (Figs. 2B and 2D). The negative surface charge of microbubbles directly supplied oxygen to the root surface and positively stimulated growth (Takahashi, 2005), thereby increasing fresh weight of radish sprouts and wheat sprouts when applying oxygen nanobubbles compared to the control plot. For leafy vegetables, leaf length and leaf width of red mustard tended to decrease in NB 33\% and NB $100 \%$ treatment plots (Figs. 1A-1D), but fresh weight and dry weight increased, which can be interpreted as growth as the plant size becomes dense. Not only color and shape of leafy vegetables but also how dense they are is a significant factor in evaluating the optimum harvest period. Leafy vegetables that are not yet mature or too mature for harvest tend not to be dense or have too hard mesophyll (Gil and Tudela, 2020). Thus, healthy leaf growth of 
sprouts and leafy vegetables can be made possible by applying NB $100 \%$ oxygen NB.

\section{Conclusion}

This study could not precisely control the DO for seed germination and leaf growth since horticultural substrates are used, and did not show a consistent seed germination response in sprouts and leafy vegetables compared to previous studies using hydroponics. However, for radish sprouts and wheat sprouts, root length became longer and fresh weight increased in DO concentration of 20.93 $\mathrm{mg} \cdot \mathrm{L}^{-1}$. In leafy vegetables, fresh weight and dry weight increased in both leafy vegetables and sprouts excluding pak choi, showing that oxygen NB treatment enables growth stimulation of vegetables. There is a difference in the scope of DO concentration that enables stable growth of sprouts and leafy vegetables within the scope of oxygen $\mathrm{NB}$ treatment, and for leafy vegetables, the adequate scope of DO concentration is $39.29 \mathrm{mg} \cdot \mathrm{L}^{-1}$.

\section{References}

Abu-Shahba, M.S., M.M. Mansour, H.I. Mohamed, and M.R. Sofy. 2021. Comparative cultivation and biochemical analysis of iceberg lettuce grown in sand soil and hydroponics with or without microbubbles and macrobubbles. J. Soil Sci. Plant Nutr. 21(1):389-403.

Ahmed, A.K.A., X. Shi, X. Hua, L. Manzueta, W. Qing, T. Marhaba, and W. Zhang. 2018. Influences of air, oxygen, nitrogen, and carbon dioxide nanobubbles on seed germination and plant growth. J. Agric. Food Chem. 66(20):5117-5124. https://doi.org/10.1021/acs.jafc.8b00333

Bailly, C., H. El-Maarouf-Bouteau, and F. Corbineau. 2008. From intracellular signaling networks to cell death: The dual role of reactive oxygen species in seed physiology. C. R. Biol. 331(10):806-814. https://doi.org/10.1016/j.crvi.2008.07.022

Bok, G.J., J.Y. Choi, H.J. Lee, K.Y. Lee, and J.S. Park. 2019. Microbubbles increase glucosinolate contents of watercress (Nasturtium officinale $\mathrm{R}$. Br.) grown in hy- droponic cultivation. Prot. Hortic. Plant Fact. 28(2):158165. https://doi.org/10.12791/KSBEC.2019.28.2.158

Both, A.J., L.D. Albright, R.W. Langhans, R.A. Reiser, and B.G. Vinzant. 1994. Hydroponic lettuce production influenced by integrated supplemental light levels in a controlled environment agriculture facility: Experimental results. ISHS Acta Hortic. 418:45-52. https://doi.org/10. 17660/ActaHortic.1997.418.5

Ding, X., Y. Jiang, H. Zhao, D. Guo, L. He, F. Liu, Q. Zhou, D. Nandwani, D. Hui, and J. Yu. 2018. Electrical conductivity of nutrient solution influenced photosynthesis, quality, and antioxidant enzyme activity of pakchoi (Brassica campestris L. ssp. chinensis) in a hydroponic system. PLoS One 13(8):e0202090. https://doi.org/10.1371/journal.pone.0202090

Du, Y.D., W.Q. Niu, X.B. Gu, Q. Zhang, B.J. Cui, and Y. Zhao. 2018. Crop yield and water use efficiency under aerated irrigation: A meta-analysis. Agric. Water Manag. 210:158-164. https://doi.org/10.1016/j.agwat.2018. 07.038

Ebina, K., K. Shi, M. Hirao, J. Hashimoto, Y. Kawato, S. Kaneshiro, T. Morimoto, K. Koizumi, and H. Yoshikawa. 2013. Oxygen and air nanobubble water solution promote the growth of plants, fishes, and mice. PLoS One 8(6):e65339. https://doi.org/10.1371/journal. pone.0065339

Gil, M.I. and J.A. Tudela. Leafy vegetables: Lettuce, escarole, and radicchio. 2020. In M.I. Gil and R. Beaudry. (Eds.). Controlled and modified atmospheres for fresh and fresh-cut produce (pp. 537-543). Cambridge, IN: Academic Press.

Greenway, H., W. Armstrong, and T.D. Colmer. 2006. Conditions leading to high $\mathrm{CO}_{2}(>5 \mathrm{kPa})$ in waterlogged-flooded soils and possible effects on root growth and metabolism. Ann. Bot. 98(1):9-32. https://doi.org/10.1093/aob/mcl076

Hwang, M.S., S.H. Oh, J.I. Lee, J.W. Han, and J.M. Kim. 2016. Effect of nanobubbles on the seed germination. Korean J. Plant Resour. 29(5):574-578. https://doi.org/ 10.7732/kjpr.2016.29.5.574

Ikeura, H., H. Takahashi, F. Kobayashi, M. Sato, and M. Tamaki. 2017. Effect of different microbubble generation methods on growth of Japanese mustard spinach. J. Plant Nutr. 40(1):115-127. https://doi.org/10.1080/ 


\subsection{6 .1201498}

Jeong, S.H., D.C. Kim, and J.G. Han. 2017. The fundamental study on the soil remediation for copper contaminated soil using nanobubble water. J. Korean Geosynth. Soc. 16(1):31-39. https://doi.org/10.12814/ jkgss.2017.16.1.031

Jun, S.Y., T.H. Kim, and S.H. Hwang. 2012. The consumption status and preference for sprouts and leafy vegetables. Korean J. Food Preserv. 19(5):783-791. https://doi.org/10.11002/kjfp.2012.19.5.783

Jung, D.H., S.H. Lee, Y.H. Kim, and J.G. Han. 2016. Experiment study on the improvement compressive strength of cement mortar with nano bubble water. J. Korean Geosynth. Soc. 15(2):13-17. Retrieved from http:// kgss.or.kr/webzine/201605/pdf/03_skNews_01.pdf

Kim, J.S., W.H. Kang, T.I. Ahn, J.H. Shin, and J.E. Son. 2016. Precise, real-time measurement of the fresh weight of lettuce with growth stage in a plant factory using a nutrient film technique. Korean J. Hortic. Sci. Technol. 34(1):77-83. https://doi.org/10.12972/kjhst.20160020

Lee, J.M. 2017. Physicochemical characteristics and antioxidant effects of red mustard (Brassica juncea L.) leaf using different drying methods. Korean J. Community Living Sci. 28(4):515-524. https://doi.org/10.7856/kjcls. 2017.28.4.515

Lee, M.J., S.K. Park, M.N. Jung, and D.H. Kim. 2011. Studies on germination and preference for consumers in sprouts. J. Korean Soc. People Plants Environ. 14(2):93-101.

Lee, S.Y., H.Y. Weon, J.J. Kim, and J.H. Han. 2016. Biocontrol of leaf mustard powdery mildew caused by Erysiphe cruciferarm using Bacillus velezensis YP2. Korean J. Pestic. Sci. 20(4):369-374. https://doi.org/ 10.7585/kjps.2016.20.4.369

Liu, S., S. Oshita, Y. Makino, Q. Wang, Y. Kawagoe, and T. Uchida. 2016. Oxidative capacity of nanobubbles and its effect on seed germination. ACS Sustain. Chem. Eng. 4(3):1347-1353. https://doi.org/10.1021/acssuschemeng. $5 \mathrm{~b} 01368$

Liu, S., Y. Kawagoe, Y. Makino, and S. Oshita. 2013. Effects of nanobubbles on the physicochemical properties of water: The basis for peculiar properties of water containing nanobubbles. Chem. Eng. Sci. 93:250-256. https://doi.org/10.1016/j.ces.2013.02.004

Podsędek, A. 2007. Natural antioxidants and antioxidant capacity of Brassica vegetables: A review. LWT-Food Sci. Technol. 40(1):1-11. https://doi.org/10.1016/j.lwt. 2005.07 .023

Rural Development Administration (RDA). 2013. Agricultural technology guide: 71. Hydroponics. RDA, Jeonju, Korea. Retrieved from https://www.nongsaro.go.kr/portal/ps/ $\mathrm{psb} / \mathrm{psbx} / \mathrm{cropEbookFileViewPop} . p s ?$ indexPage=8\&indexBasePage $=-1 \&$ cropsEbookFileNo $=00001 \&$ ebookCo $\mathrm{de}=143$

Rural Development Administration (RDA). 2018. Agricultural technology guide: 140. Leafy vegetable. RDA, Jeonju, Korea. Retrieved from https://www.nongsaro.go.kr/portal/ps/psb/psbx/cropEbookFileViewPop.ps?indexPage $=234 \&$ indexBasePage $=-2 \&$ cropsEbookFileNo $=00001 \&$ ebookCode $=33$

Sang, H., X. Jiao, S. Wang, W. Guo, M.K. Salahou, and K. Liu. 2018. Effects of micro-nano bubble aerated irrigation and nitrogen fertilizer level on tillering, nitrogen uptake and utilization of early rice. Plant Soil Environ. 64(7):297-302. https://doi.org/10.17221/240/2018-PSE

Seo, M.H. 2013. Sprouts vegetables. Korean Soc. Hortic. Sci. 5:123-126.

Song, H.J., S.H. Oh, B.S. Yim, J.I. Lee, B.H. Lee, and J.M. Kim. 2013. A study on existence and lifespan of $\mathrm{O}_{2}$ nano-bubbles in water. Korean Soc. Precis. Eng. 10:453-454.

Takahashi, M. 2005. Potential of microbubbles in aqueous solutions: Electrical properties of the gas-water interface. J. Phys. Chem. B. 109(46):21858-21864. https://doi.org/10.1021/jp0445270

Yoon, Y.H., W.J. Kim, J.H. Jung, H.M. Lim, and J.R. Roh. 2013. Preliminary investigation on evaluation test for water quality improvement by micro-nano bubbles. Korean Soc. Civ. Eng. 10:2934-2936.

Zhou, Y., B. Zhou, F. Xu, T. Muhammad, and Y. Li. 2019. Appropriate dissolved oxygen concentration and application stage of micro-nano bubble water oxygation in greenhouse crop plantation. Agric. Water Manag. 223: 105713. https://doi.org/10.1016/j.agwat.2019.105713 